\title{
Could ASEAN be an economic and political counterbalance to rising china in the region?
}

\author{
Nguyen Hoang Tien ${ }^{1, *}$, Ha Van Dung ${ }^{2}$
}

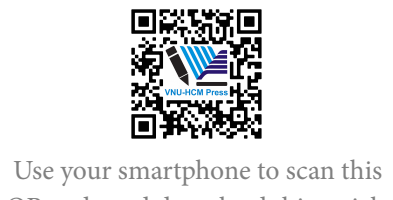

QR code and download this article

\begin{abstract}
National security is one of the most critical elements for the society, economy and the political system of a given country. Especially, it is unconditionally important for the stability, sustainability and prosperity of national development. Moreover, it is also unconditionally the top priority for all ASEAN countries that have to cope with the continually rising China in all aspects of development of the Asia-Pacific region. The present article is using case study analysis and comparative empirical analysis as a research methodology to investigate and find out the right answer to the question exposed in its title. The article approaches and treats security and military science as interdisciplinary area of contemporary research. At the same time they are considered as one of the branches of social science. In the beginning of $21^{\text {st }}$ century, the economic relations as well as the geo-political relations between China and ASEAN have made many progresses and positive changes towards right direction, in line with common principles of peaceful and secured development in the region. However, this current relationship still shows many difficulties and obstacles that the two sides need to solve and overcome in order to benefit from the existing potentials of each other. The first aim of this present article is to focus on overall complex relationship between ASEAN and China that could pose real threat and danger to the ASEAN nations in terms of its inability to counterbalance the rising China in the Asia Pacific region. The second aim of the article is to propose some useful recommendations and viable solutions to guard the safety of the people, security in the society and economy, the political existence of the ASEAN bloc.
\end{abstract}

Key words: ASEAN, China, economic development, military issues, South China Sea
${ }^{1}$ Saigon International University

${ }^{2}$ Ho Chi Minh City Banking University

Correspondence

Nguyen Hoang Tien, Saigon International University

Email: nguyenhoangtien@siu.edu.vn

History

- Received: 3/1/2019

- Accepted: 28/4/2019

- Published: 30/9/2019

DOI : 10.32508/stdjelm.v3i3.565

\section{Check for updates}

\section{Copyright}

(c) VNU-HCM Press. This is an openaccess article distributed under the terms of the Creative Commons Attribution 4.0 International license.

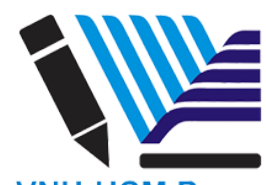

VNU-HCM Press

\section{OVERVIEW OF ASEAN-CHINA RELATIONSHIP}

The end of the Cold War has opened up a vast space for peace and development for each nation in particular and for each region in general. The main trend of humanity is dialogue and confrontational cooperation. Economic and political power is the most important measure of strength for each nation. China has intensified mutual exchanges, security and defense cooperation with ASEAN countries as Chang Wan, Defense Minister of China (16/10/2015) affirmed that "dialogue and cooperation in the field of defense and security is an important element of the China-ASEAN strategic partnership; China wants to work with ASEAN to maintain security and stability in the region; China will continue to coordinate and cooperate with ASEAN countries in multilateral mechanisms such as the ASEAN Plus Three (ADMM Plus) and the Regional Forum (ARF)" ${ }^{1}$. As a more specific example, the journalist Sebastian Strangio based in Phnom Penh, the capital of Cambodia, has commented: "China's axis rotation is particularly noteworthy in Laos", adding at the same time that "for at least a decade, Laos has become the main conduit for penetration of China in Southeast Asia”. According to Chheang Vannarith, visiting professor at Leeds University in England, China now also needs Cambodia as a trustworthy partner in the Southeast Asia. China enlists Cambodian support in Indochina and the Mekong river delta region to reinforce its influence in the Asia-Pacific region ${ }^{2}$.

The establishment of the ASEAN Community and the ASEAN-China Free Trade Area (ACFTA) has helped facilitate bilateral economic, trade and investment flows. The ASEAN Community will help to promote the integration in political, economic and cultural aspects of ASEAN, which is conducive to the formation of a common market and a joint production base in the region with a total population of 600 million people, with a total economic output of $\$ 2$ trillion and with the highest economic integration level in the region $^{3}$. The ASEAN Economic Community (AEC) will promote free flow of goods, services, capital and human resources in the region, and the economic 
growth of ASEAN is expected to accelerate. According to an investment report released by ASEAN in November 2015, total foreign direct investment (FDI) attracted by all ASEAN countries has increased for three consecutive years, making it the largest destination for FDI amongst developing countries in the region, creating new opportunities to develop ChinaASEAN economic and trade relations. China's economy has grown rapidly since economic reforms and open door policy started in 1979. The entry to the World Trade Organization (WTO) in November 2001 marked another stage of China's economic reform and opening up to the world, making further improvements in its economic efficiency and competitiveness. The China's economic scale, dynamic growth and WTO accession are having significant effect on the ASEAN economies and beyond. ASEAN's response to China's rising economy is mixed. Although China's prosperity and global integration are good for and strongly welcome by the region, and China will provide a large and rapidly growing market for ASEAN, especially for the natural resource-based products, ASEAN perceives a threat that arises from China's ability to enter their market with constantly growing range of manufacturers. China's huge and cheap labor force along with its cost competitiveness can undermine ASEAN's market share in its main world markets such as US, EU, Japan and threaten domestic market of ASEAN industries. Moreover, China's cost competitiveness and rapidly growing domestic market may divert FDI flows from ASEAN.

According to Prof. Liu Ying of the Chongqing Institute of Financial Studies at the People's University of China, at the beginning of 50th anniversary of ASEAN's founding, the relationship between China and ASEAN had grown into a strongest and most vibrant partnership in the world, in which economic, trade and investment relations between them are constantly growing ${ }^{1}$. With its importance, ASEAN has become a geopolitical space as well as China's major economic counterpart. Two-way investment between China and ASEAN started from low level but took place strongly. ASEAN countries are increasingly becoming the major FDI destination for Chinese enterprises with the number and scale of investment projects and industrial parks constantly expanding, shifting from the traditional industrial processing to new areas such as currency service, e-commerce, cultural exchange and entertainment. In 2013, China has invested \$ 8.64 billion in ASEAN countries, up $7.1 \%$ compared to last year. As of June 2014, ChinaASEAN two-way investment reached nearly \$ 120 billion, of which the total investment of ASEAN coun- tries in China reached over $\$ 80$ billion, the total investment of China in ASEAN was nearly \$ 40 billion. In 2013, Singapore became China's largest ASEAN investor $^{2}$.

The relationship between China and ASEAN has grown tremendously; the political trust between the two sides has been constantly strengthened and has achieved substantial successes in mutual cooperation in all fields. ASEAN is China's third largest trading partner, while China is the first country to establish free trade area (FTA) with ASEAN and has been the largest trading partner of ASEAN since 2009. China and ASEAN promote mutually beneficial economic cooperation. China and ASEAN have established strategic partnership as a platform for the economic, trade and investment cooperation, contributing to making relationship between China and ASEAN one of the successful cooperation models between ASEAN and its strategic partners. In the China-ASEAN relationship, along advantages brought about by the general context and dynamic economic development, in the political and security landscape there are found many uncertainties. The relationship between China and ASEAN still faces some difficulties, especially the disagreement between China and some of ASEAN countries in the South China Sea. The trade deficit between ASEAN countries and China continues to increase. Due to the full effect of the ACFTA in 2010, trade volume between ASEAN and China has shifted from a surplus to a deficit of $\$ 45$ billion in 2013. In particular, manufactured goods, especially machinery and electronics, are still dominant in the bilateral trade. FDI from China has yet to play an important role in ASEAN and FDI flow from China to ASEAN is still low compared to China's total FDI outflows. According to data from the China Ministry of Commerce, China contributes $2.3 \%$ of total FDI received by ASEAN and China's FDI outflows to ASEAN account for only $6.7 \%$ ( $\$ 35.7$ billion) of total FDI outflows of China in $2013^{2}$. The economic cooperation between ASEAN and China, although developing rapidly since the Cold War, will be unsustainable if not being based on political security to address the key challenges in this partnership.

\section{NATIONAL SECURITY'S THEORETICAL FRAMEWORK}

According to contemporary dictionaries, most often, security is defined as a state of certainty of an individual, a group of individuals or a whole nation to counter the crisis situation. Security is usually 
seen as a freedom from or resilience against potential harm (or other unwanted change) from external forces. Beneficiaries of security may be persons and social groups, objects and institutions, ecosystems, and any other entity or phenomenon vulnerable to unwanted change by its environment. Security mostly refers to protection from hostile forces, but it has a wide range of other senses, for example, it could be understood as: the absence of harm; the presence of essential goods (energy security), the resilience against potential damage; the secrecy and privacy; and finally, a state of mind (emotional security) ${ }^{4}$. The most general definition of security is provided by the Dictionary of Social Sciences issued by UNESCO in which according to Daniel Lerner, in the most literal sense, security is virtually identical with certainty (safety) and it means no physical threat (or danger) or full protection against it ${ }^{5}$.

Oftentimes, in various studies in the field of social sciences, security is presented as the ability to survive, independence, identity or certainty of development. In security analyses, the occurrence of two negative phenomena, that are challenge and threat, is considered. Challenges are understood as the emergence of new situations in which there are urgent needs requiring the formulation of responses and taking appropriate measures to ensure a certain state of security. They can turn into threats, the real dangers to the security. Threats can be a reflection of the real state of affairs or exaggerated ideas. They may refer to the assessment of a certain state at a specific historical moment (current threat) or refer to an extrapolation of anticipated developments and accompanying adverse, unwanted changes (potential threats) ${ }^{6}$. According to Swiss scholar Daniel Frei, the state of security only occurs when there is no real threat (objective factor) and no sense of threat (subjective factor) ${ }^{7}$.

According to Morton Berkowitz, national security can be the most suitably defined as its ability to protect its internal values against external threats. Ensuring acceptable level of national security is one of the main functions of government and each country has its own national security (management) system and national security strategy ${ }^{8-11}$. The proper functioning of national security system including law enforcement services, training and research institutes, rescues services responsible for security and (local) government bodies involved in such activities, depends to a large extent on their interdependency and their proper exchange of information ${ }^{12}$. National security remains closely related to international security, which can be considered both at the regional and global level. United Nations experts in the study on the concept of security have defined international security as a state in which nations believe that they are not threatened by military attack, pressure or economic compulsion (sanction), and are therefore capable of freedom of development and progress. They further argue that international security is the result and the sum of security of each and all countries, the members of the international community. Accordingly, international security cannot be provided without a full international cooperation between countries and involvement of international organizations and individual citizens ${ }^{13}$.

There is no doubt, therefore, that security is the supreme need of people and social groups and at the same time the most important goal ${ }^{14}$. It aims to satisfy the most important needs of survival, stability, sustainability and predictability of development, wellbeing and finally human happiness. Multan claims that security can be defined not only as a specific goal, but also as a succession. This means that we are not aware of what it is until we are threatened by its loss ${ }^{15}$. It is assumed that national security consists of relations and links between all of its constituent elements ${ }^{16}$. A common feature of most security definitions is to describe it as a process. Security is not a given state of affairs but a continuous social process in which operating entities try to improve the mechanisms that ensure their sense of security. All components of this process, more or less measurable, having the character of both dependent and independent variables, are subject to numerous changes conditioned by the internal situation of a nation, its regional and international situation ${ }^{17,18}$.

Globalization shapes processes that take place in all spheres of human activity, including economy and security. Economy and security are areas of basic importance for human functioning in the contemporary world, mutually penetrating and dependent on each other. Security and the idea of partnership for peace are one of many aspects and it is treated as a guarantor of sustainable competitiveness of enterprises and sustainable development of all economies ${ }^{19-21}$. Globalization is not a new phenomenon, but it has gained significance only thanks to the development of technology, which enabled the exchange of information in real time and the movement of people and goods globally in a short time. It means an extensive network of economic and informational connections connecting different parts of the world ${ }^{22}$. Globalization is inextricably linked to the development of humanity. In pursuit of development, faster communication, better technologies, man has managed to minimize the differences between societies of different countries, 
at the same time created common ground for mutual cultural exchange. The globalization process cannot be reversed, we are surrounded by it, and we live with it. Although the globalization process has been going on for several centuries, it has been particularly intense in recent years. Governmental institutions that are responsible for ensuring security should be able to limit the negative effects of globalization on social and economic spheres. It is necessary to take action to ensure social and economic security not only at the national level, but also at international and supranational level. Governments conclude agreements on economic cooperation, join military and economic alliances. It is in these agreements and alliances that clauses on mutual cooperation in the field of security are included. Because globalization is a transnational phenomenon, security activities also have transnational features. Globalization means a process of growing interconnectedness between societies leading to events in one part of the world increasingly affecting people and societies in remote locations ${ }^{23}$. Globalization is multidimensional and asymmetrical. Multi-dimensionality consists in including various spheres of human activity in these processes: political, economic, social, technological, cultural, ecology and security issues which are closely related to each other and affect each other ${ }^{24}$. Asymmetry depends on a different rate of change in individual fields and on the emergence of opposite benefits and phenomena, e.g. qualified immigrants accelerate the development of the host country, at the same time weaken the development of the country of origin, environmentally burdensome production releases the country of origin from it, but accelerates the degradation of the country to which it has been moved; taxes of transnational enterprises are paid in the home country ${ }^{25}$.

The most important economic benefits for many countries due to globalization include the inflow of foreign capital (FDI), access to information, modern technologies, expanding the market offer of products, increasing the pressure for modernization and increasing the efficiency of economic activity, return on investment, creating new jobs, boosting exports, participation in the international division of labor, economic growth, raising the standard of living, civilization advancement. Globalization forces many companies to become more competitive and can be a way to develop poorly developed countries as it can fuel social, political and economic changes ${ }^{26}$. In the socio-cultural sphere, the main benefits of globalization processes are: increasing access to diversified cultural offer, growing intercultural exchange, openness to cultural diversity, awareness of its sensitivity, blurring the boundaries between what is national and what is foreign, creating similar cultural products in different societies, strengthening its both orientation towards standardization and orientation towards customization ${ }^{27}$. At the same time, these processes have a positive effect on intercultural communication, the opportunity to get to know each other better and understand different customs. Positive consequences of globalization in the political sphere are: dissemination of democratic institutions and procedures, gradual universalization of human rights, unification of international collaboration, cooperation and peaceful settlement of disputes, growing formalization and institutionalization of international relations, striving for regional and international integration, strengthening and empowering communities, greater access to various sources of information, greater opportunities to publicize their own problems and interests, bigger influence on power, self-organization thanks to modern means of communication and the dispersal of power $^{28}$.

As stated above, ensuring security is one of main functions of government and in that area one has to deal with a wide range of threats and challenges constituting real concerns for the whole society, especially for social groups and individuals ${ }^{9,29}$. Security issues researched in literature and practices are presented as multidimensional problems of multiple levels ${ }^{30}$. Security issues should not be confined to economic, social, energy and environmental aspects and their interaction $^{31}$. Additionally, security research is generally presented as a problem of two levels. First level is focused on individuals and social groups while the second level deals with the security issues in a national level. Research on both levels, however, is very often concentrated on the life or health threat in direct connection with conventional war conflicts, terrorism, organized crime, political or social persecution and natural disasters. Nevertheless, such understanding security does not comply with the present reality. There exists a wide range of scientific studies proving that the present understanding of security consists of several dimensions which might not be directly linked to actual traditional war activities. The human security in a broad sense could be jeopardized also by unfair economic, trade and social practices or abuse of political power by governmental bodies, corruption scandals in national economies, and discrimination of minorities or ethnic groups, drugs trafficking and black markets ${ }^{32}$. In last few decades, the understanding of security has been changing. New areas emerged 
which may influence security facets, which were not urgent earlier. Now those facets can endanger individual persons or even nations. Breaches of cyber security, separatist attacks or intense cyber wars are becoming more usual than conventional wars in physical space. Violations of cyber security may cause great damage, ruin businesses or even temporarily paralyze full-fledged functioning of individual countries or regions ${ }^{33}$. Table 1 presents the most important issues of security that could impact all of us, enterprises and organizations, government and society, groups and individual citizens, regardless of the nationality. These security issues well researched in the literature of military science and divided clearly into two main categories (unconventional and conventional) at international and regional level (i.e. for ASEAN bloc as a whole) (Table 1) could be, for the needs of national security analysis, adopt ed (regrouped) into other categories (external and internal) (Table 2) at the national level (i.e. for each of ASEAN's economies and societies). External security issues, in contrary to internal ones, mean that they are out of the reach and full control of the government of single country. Thus, regional cooperation is needed and intergovernmental mechanisms should be formed to find measures to cope with them.

\section{METHODOLOGY OF RESEARCH}

The security science is seen as much broader than military science as it includes also non-military issues of the international, regional, supranational, national security and individual safety. Security science is an independent and original research discipline that strives to obtain a comprehensive, coherent panorama (multi-aspect, multi-dimensional, multi-perspective) of the reality from point of view of satisfying individual and collective need for security. The development of methodology for research in security science is just both separate and, as well, being at the intersection of other well-rounded sciences, such as political science, psychology or sociology. Security science in the classification of sciences is a scientific discipline that belongs to the field of social sciences. Moreover, due to the specific objects, subjects and methods of research, and also due to the type of research statements (hypotheses) formulated and practical directives, security science is considered as an interdisciplinary science. We are assuming a fairly obvious statement that scientific methods appropriate for security science are, among st those very popular in the social sciences, methods of empirical research and comparative analysis. These method s need a verification of research hypotheses or require searching for answers to the research questions formulated by scholars ${ }^{34}$.

As a result, many scientific papers are empirically investigating security issues and concerns, typical for the economic and military powerhouses in the world. Those security issues are divided into two afore mentioned groups: conventional and unconventional. In contemporary world, we are observing the rise in importance of unconventional security issues, their scope and range need to be paid more attention. Nonetheless, it doesn't mean that the conventional security issues are decreasing in their importance and become less influential. For diminutive countries that are less influential and less paid attention by the world, at least at the moment, such as many of the ASEAN states, the impact and the significance of unconventional security issues are less obvious and the division of security issues into such category might be unjustified. In case of those countries, the division of security issues into internal and external ones seems to be convincing and as such we are observing the rise in importance of internal security issues, their frequency and intensity rather than the external security issues originating from outside as a result of a political game of superpowers both in the region and across the globe. However, f or the ASEAN bloc as a whole, the balance between the impact, the significance of un-conventional and conventional security issues should be preserved and paid appropriate attention as ASEAN always wish to be a key regional player and to counterbalance rising China in global stage. Having that in mind, in this present article we relate to the ASEAN's unique historical and geo- political context in order to draw comprehensive implications and propose some viable solutions for ensuring safety of the people, security in the society and political existence of the bloc, contributing to the overall global security and stability in the region due to its geo-strategic, geo - political and geo-military position. We carry out comparative studies between ASEAN and China based on sound theoretical framework encompassing selected security issues and security concerns in respect of two suggestively proposed interrelated dimensions ${ }^{25,35-37}$ : macroeconomic security (including mainly foreign trade and investment relations) and existential (to be or not to be) security (including geo-strategic, geo-political, geo-military position and identity). The security issues considered under such dimensions always come together, strictly determine each other and, of course, will certainly pose real big challenges for ASEAN. Consequently, if those security issues and concerns are not solved and 
Table 1: Security issues and concerns - framework for global \& regional security analysis

\begin{tabular}{ll}
\hline Conventional security issues & Unconventional security issues \\
\hline $\begin{array}{l}\text { Asymmetry of interests (of developed and developing } \\
\text { countries) }\end{array}$ & The rise of cryptocurrency \\
Illegal migration & Cyber-threats: -Information warfare \\
Global terrorism, extremism and Nationalism & Cyber-threats: -Cyber-terrorism \\
National defense spending & Cyber-threats: -Cyber-crime \\
Regional conflicts and territorial disputes & Cyber-threats: -Cyber-espionage \\
Trade and currency warfare (protectionism) & \\
Energy and environmental concerns & \\
\hline
\end{tabular}

Source: Author's synthesis

Table 2: Security issues and concerns - framework for national security analysis

\begin{tabular}{lc}
\hline External security issues & Internal security issues \\
\hline Climate change and natural disaster & $\begin{array}{l}\text { Internal asymmetry of social } \\
\text { interests }\end{array}$ \\
Energy and natural resources disputes & Political instability \\
Territorial (land, sea water and air space) disputes & Corruption scandals \\
$\begin{array}{l}\text { Sustainable economic growth and global trade warfare consequences } \\
\text { (protectionism) }\end{array}$ & \\
\hline
\end{tabular}

Source: Author's

dealt properly and, especially in a close, interactive relation with each other, they could hinder the whole process of ongoing integration, consolidation and development of ASEAN in order to counterbalance rising China in global and regional stage, in a pursuit and defense of its core, undisputed interests. Those security issues, both in macroeconomic and existential terms are the basis for the ASEAN-China comparative study to find out disadvantages and advantage $s$ of ASEAN (in relation to China) in each of detailed aspects of mentioned security issues. The result of carried out comparative study is served to find out an answer to the question introduced in the title of this article: "Could ASEAN be an economic and political counterbalance to rising China in the region?"

\section{RESULTS}

\section{Comparing ASEAN and China in the Macroeconomic Aspect of Security Issues}

There is a real concern that ASEAN countries are increasingly reliant on Chinese economy and China's trade and investment influence is spreading rapidly. For example, Philippines have been battered by China's ban on banana imports in 2012 on the grounds that it does not guarantee quarantine safety standards. The ban was lifted several years later when President Rodrigo Duterte decided to pursue a friendlier stance towards Beijing. According to Duterte, in the long run, Philippines still benefits from China's economic growth and Philippines simply cannot ignore China due to its huge and potential market. However, his anxiety is great because China is aware of its power and knows how to use it accordingly. Any sector in ASEAN economies that depends too much on the outside, such as Thai tourism industry, Philippines banana industry and Indonesian fishing industry, are vulnerable due to China's erratic behavior. "We can imagine how easy it would be for China to hinder others' industries", said Dane Chamorro, Southeast Asia 's director of Risk Control in Singapore ${ }^{38}$. More than a year ago, leaders of the ruling National League Party in Malaysia expressed concern after Malaysian Prime Minister Najib Razak brought about \$34 billion worth of economic cooperation agreements during a visit to Beijing. They said the deal would not only pave the way for billions of dollars in debt, but also open the door for China to exert directly influence on Malaysia's internal affairs. The railway project connecting Thailand and Southern China through Lao People's Democratic Republic also met with strong opposition. Many comments in Thailand criticize China's too excessive demands 
on this project as well as China' s overly high lending rates. However, finally, Thailand's cabinet approved the construction of the first phase of this project. The $\$ 7$ billion railway project is just one of many infrastructure development project s serving China's economic expansion policy in ASEAN. The general view of the plan to build China's $\$ 7$ billion high-speed railway project in Laos is that this serve to connect Laos' economic interests with China, at the same time aiming at increasing the influence of China in Laos ${ }^{39}$. In Myanmar, China's \$ 10 billion pipeline project involving in the well-known "One Belt One Road" (OBOR) project has sparked protests. People in Myanmar were concerned because this project is threatening the environment and local households were not fully compensated when being relocated to get the land for the project implementation. "China does not do anything to fulfill its obligations as mentioned in Aung San Suu Kyi's report", said Ma Mar Cho, one of the protest leaders who spoke to Reuters ${ }^{40}$. Greater economic dependence on China is another concern for some of ASEAN countries that suffered fundamental weaknesses in their economy. For example, consumption growth in Indonesia and Philippines is stagnant; despite previously both countries have experienced higher level of GDP growth. FDI flows to Indonesia, except from China, are slowing down. In Thailand, the baht currency has been appreciated, putting high pressure on exporters. With significant connectivity and cross-border trade with some countries, recent reports suggest that China is expanding its economic impact in ASEAN through infrastructure development investments. At the same time, China and some ASEAN countries are trying to resolve disputes over maritime rights in the South China Sea. If these disputes remain unsettled, it may be possible for Beijing to use its economic leverage to promote strategic goals in the South China Sea and beyond. Furthermore, in a longer perspective, China can also try to acquire infrastructure assets in ASEAN countries to serve its national interests. The head of the Department for ASEAN Affairs under Thailand's Ministry of Foreign Affairs, Suriya Chindawaongse, emphasized this important fact at the June 2018 negotiation on Code of Conduct in the South China Sea $(\mathrm{COC})^{41}$. ASEAN's trade with China has tripled during period 2005-2015, that is higher than the increase in intra-ASEAN trade and trade with South Korea. The share of advanced economies in ASEAN' s total trade has been declining, while China's share is increasing. South Korea's contribution is undoubtedly rising, but still modest compared to China's. As multinationals have been engaged in individual production activities in many countries over the past few decades,
China and the ASEAN economies have become interconnected in a network of production and logistics systems, thus increasing their interdependence. According to national data, by 2015, all the ASEAN economies, except Singapore, had higher trade deficit with China during the period 2008-2015. This has led to concerns for national policymakers to rethink about their foreign trade policies with China. China is an important destination for ASEAN's exports and more important for its imports to serve its needs of production and consumption. This proves that China is benefiting more from its access to ASEAN market rather than the opposite. No other trading partner, except the ASEAN itself, has such an important position for most of the exports and imports of all ASEAN economies. Since the China-ASEAN Free Trade Area (CAFTA) was created in 2010, China-ASEAN trade has grown rapidly, with an average annual increase of nearly $20 \%$. Regarding free movement and tourist industry, in 2016, ASEAN welcomed 18.61 million Chinese tourists, accounting for $17 \%$ of the total number of tourists to $\mathrm{ASEAN}^{42}$. It can be said that the importance of China in the entire ASEAN trading model is increasing. Particularly for Vietnam, Thailand and Malaysia, the countries with a growing trade deficit with China, they are more dependent on China for imported goods and raw materials. In 2013, Vietnam's trade deficit with China was more than $\$ 23$ billion; in 2014 it was nearly \$ 29 billion; in 2015 it was more than \$ 33 billion; in 2016 and 2017 it has dropped to over $\$ 28$ billion and over $\$ 22.7$ billion respectively ${ }^{43}$. Importantly, China is a key export market for some of ASEAN countries, led by Laos and Myanmar. Based on this, it can be seen that the trade dependence of ASEAN countries on China is high compared to other trading partners. That is likely to put China in a stronger position to push up their political agenda in the region, for example, the maritime claims or the pressure on smaller ASEAN states to maintain distance from the US security and military presence in Asia. Among ASEAN countries, China regards Cambodia as a cordial friend and leverages relationship with this country to influence regional policy decisions as it has ever done in the past. In another area, the importance of China as a foreign direct investor is still modest. China's FDI is only important for Laos, Cambodia and Myanmar. However, the share of Chinese FDI in A SEAN is constantly increasing. "ASEAN is an attractive FDI destination for China because of its fast growing market and population. Developing countries in ASEAN need FDI to offset the irfiscal imbalance and meet infrastructure development needs. China will bring in capital and 
expertise and China's investment in ASEAN will continue to grow due to the OBOR initiative", said analyst Lee Ju Ye from Maybank in Singapore ${ }^{44}$. China dominates ASEAN in terms of trade exchange and maintains its superior position as the largest trading partner with all ASEAN countries. On the contrary, for China, ASEAN are the third largest trading partner, while for the US, ASEAN is only the fourth largest trading partner. However, the US still dominates in ASEAN in the field of FDI as the region received total of $\$ 226$ billion in $2015^{45}$. The fact that a number of countries, such as Thailand, the Philippines or Malaysia, has slowed down in 2015 is a testimony to the fact that most of them are experiencing a sharp drop in exports as a result of the slowdown in Chinese economy. Thus, it can be said that the surge in trade exchange between China and ASEAN is only shortlived and depends largely on Chinese GDP growth that has been slowed down in recent years. While, compared to the level of large-scale and long-term investments in the ASEAN, China cannot compare with the US and other world economic powerhouses ${ }^{46}$. Table 3, for the illustration purposes, will present two-way FDI, ODA flow from ASEAN to China and from China to ASEAN; two-way import, export from ASEAN to China and from China to ASEAN in the period 2010-2018.

\section{Comparing ASEAN and China in the Existen- tial Aspect of Security Issues}

At present, China and ASEAN countries are committed to maintaining a peaceful and stable environment to focus on mutual economic development. However, the current burning issue is South China Sea disputes, a major obstacle in strengthening cooperation between China and ASEAN. China's threat for ASEAN countries still exists, as China is constantly increasing its activities in sovereignty disputes, building illegal artificial islands in the South China Sea, boosting defense expenditure to upgrade and modernize military capability, especially the navy force. All of that have caused deep concern for all countries in the Asia Pacific region and for the international community as well. Situated in the Asia-Pacific, ASEAN is the most geo-politically, geo-strategically and geo-militarily sensitive region of the world. As Myanmar has successfully ended decades of isolation, ASEAN's policy of attracting Myanmar has been criticized by the West, but it has helped lay the groundwork for a peaceful transition from military regime to a full democracy. Comparing with the West's isolation policy in Syria, it certainly does not lead to the same result. Certainly, ASEAN is not perfect. In short, it looks like ASEAN is moving in crab's style, two steps forward, one step back and one step across. But we cannot deny ASEAN 's long-term progress in preserving its regional interest. Currently, ASEAN is the only credible platform for geopolitical engagement in the Asia-Pacific region. ASEAN is also unique in its ability to convene meetings involving all the world powers, from US and European Union (EU) to China and Russia. However, at present, ASEAN continues to be facing serious challenges. Territorial and maritime disputes in the South China Sea have created deep divisions within ASEAN, between those countries directly involved in (such as: Vietnam, Philippines, Malaysia, Indonesia and Brunei) and those countries that have nothing in common (Singapore, Thailand, Myanmar, Laos and Cambodia). The increased geopolitical competition between the US and China has created a greater threat to the cohesion of the bloc. In addition, partly due to that, domestic politic al situation of some ASEAN member states, including Malaysia and Thailand, are becoming increasingly chaotic ${ }^{49}$. From the end of the first decade of the $21^{\text {st }}$ century, both China and US are trying to draw ASEAN towards themselves.

ASEAN has become an important factor in building and maintaining political stability and security in the Asia-Pacific region. ASEAN is at the center of connecting and reconciling conflicts, promoting cooperation for peace, stability and development in the Asia-Pacific region ${ }^{50}$. The new slogan in China's foreign policy "building a community of common destiny" must start in Southeast Asia. If China succeeds in this, they will once again prove the global viability of the Chinese model ${ }^{51}$. ASEAN political thought is based on the aforementioned ASEAN Political Security Community (APSC), one of three pillars of ASEAN Community, to elevate political and security cooperation to a new height, with the participation and contribution of all possible external partners, to ensure that ASEAN member states coexist peacefully with each other and with countries in the region and the outside world in an environment of justice, democracy and harmony. The APSC is not a military bloc, not a military alliance or joint foreign policy. The APSC shall promote a comprehensive approach to security, including political, economic, cultural-social and environmental aspects; strengthen political and diplomatic cooperation, develop and share common standards of conduct; promote the trend of not using military forces and resolve all disputes by peaceful means; retain open relations 


\begin{tabular}{|c|c|c|c|c|c|c|c|c|c|}
\hline Year & 2010 & 2011 & 2012 & 2013 & 2014 & 2015 & 2016 & 2017 & 2018 \\
\hline $\begin{array}{l}\text { FDI from } \\
\text { China to } \\
\text { ASEAN }\end{array}$ & 12,5 & 11,1 & 8,6 & 7,3 & 7,1 & 11,6 & 7,8 & 11,3 & 12,4 \\
\hline $\begin{array}{l}\text { FDI from } \\
\text { ASEAN to } \\
\text { China }\end{array}$ & 9,81 & 10,23 & 12,01 & 12,4 & 12,83 & 12,3 & 13,91 & 14,1 & 15,26 \\
\hline $\begin{array}{l}\text { ODA from } \\
\text { China to } \\
\text { ASEAN }\end{array}$ & 1,3 & 1,32 & 1,49 & 1,52 & 1,72 & 2,3 & 2,341 & 2,67 & 3,2 \\
\hline $\begin{array}{l}\text { ODA from } \\
\text { ASEAN to } \\
\text { China }\end{array}$ & 2,36 & 3,128 & 4,55 & 4,66 & 5,201 & 5,123 & 5,34 & 6,142 & 6,26 \\
\hline $\begin{array}{l}\text { China's } \\
\text { export to } \\
\text { ASEAN }\end{array}$ & 124,45 & 170,08 & 204,2 & 244,04 & 272,05 & 197,24 & 256,1 & 279,1 & 282,1 \\
\hline $\begin{array}{l}\text { ASEAN's } \\
\text { export to } \\
\text { China }\end{array}$ & 117,7 & 225,12 & 320.9 & 403,6 & 437,15 & 448,7 & 468,12 & 513,6 & 625,4 \\
\hline $\begin{array}{l}\text { China's im- } \\
\text { port from } \\
\text { ASEAN }\end{array}$ & 138,56 & 192,771 & 195,821 & 199,559 & 208,214 & 143,13 & 196,4 & 235,7 & 265,14 \\
\hline $\begin{array}{l}\text { ASEAN's } \\
\text { import } \\
\text { from China }\end{array}$ & 10,55 & 200 & 38,7 & 40,1 & 42,85 & 22,4 & 43,4 & 48,61 & 14,58 \\
\hline
\end{tabular}

Source: Author's synthesis from UNCOMTRADE (UN, 2018) ${ }^{47}$ and China Customs ${ }^{48}$ report

with external partners and maintain ASEAN's central role in the regional architecture ${ }^{52}$. Chinese political thought, expressed by "Chinese dream banner", brings together four powerful, comprehensive reconstructions of China's new face based on the characteristics of Xi Jin Ping's thought. Those four comprehensive reconstructions include: (1) comprehensive wealthy social development, (2) comprehensive economic reform, (3) comprehensive national rule of law, and (4) comprehensive strict management of the China Communist Party. By February 2015, the state Xinhua News Agency determined clearly that this is the strategic layout and political platform for the country's construction and development in the period of new era ${ }^{53}$.

Both ASEAN and China are facing many challenges that might turn into the threats to their existential security. Challenges for ASEAN ahead are : (1) international terrorist organizations such as IS (Islamic States), Al-Qaeda which after heavy casualties in Iraq and Syria are turning their operations to ASEAN countries, first in Islamic island states like Indonesia and Malaysia; (2) China and US are increasingly engaged in the South East Asia, involving ASEAN countries in their geopolitical orientations. Sino-US competition puts ASEAN bloc ahead of the big challenge of recognizing and dealing with external pressures ${ }^{50}$. Challenges for China ahead are also noticeable. Xi Jin Ping's continuous pursuit of excessive control over the China Communist Party has reversed decades of attempts to institutionalize Chinese politics. During his tenure, there have been rumors of unsuccessful coup attempts, with the most recent rumors appearing in December 2017. At the same time, Xi Jin Ping's ambitions have led China from being a hidden dragon during previous leaderships to being over-stretched abroad, from South East border areas to the remote Western locations. An increasingly provocative and aggressive foreign policy, expressed by undertakings of restoring territory, is pushing other countries into the alliance to protect them from Beijing's expansionism ${ }^{54}$. On the South China Sea, ASEAN continues to reaffirm the agreed principles of the importance of peace, stability, security, safety, freedom of aerial and 
maritime navigation; to respect the rule of law to resolve disputes by peaceful means; to restrain and not to complicate the disputes; to demilitarize and to implement fully and effectively the DOC (Declaration on the Conduct of parties in the South China Sea) and soon reach the COC (Code of Conduct in the South China Sea). Accordingly, on August 06, 2017, in Manila, the capital of Philippines, the adopted and negotiated framework between ASEAN and China on COC was officially launched. In parallel, before that happened, the XVIII Congress of China Communist Party in March 2013 set out the strategy of building a maritime power, officially bringing the issue of maritime development into national defense strategy, emphasizing the building of maritime power as an indispensable choice to protect the national interest and to restore the Chinese nation. The development of China's maritime power has become particularly remarkable in the current context, as China continues to aggressively violate the sovereignty and national interests of other states in order to materialize its monopoly in the South China Sea ${ }^{55}$. The outcome of ASEAN-China collaboration in politics and security between 1997 and 2003 is that China and ASEAN signed the joint statement towards the $21^{\text {st }}$ century. Following the decision of the China-ASEAN summit in 2000, China and ASEAN signed action plan against drug trafficking. In November 2002, China and ASEAN signed the Declaration on the Conduct of parties in the South China Sea, Joint Declaration on China-ASEAN security in the field of non-traditional (unconventional) security, pledged to settle all disputes by peaceful means, laying an important legal basis for the implementation of cooperation between parties in the South China Sea. In 2003, the two sides issued the Joint Declaration on strategic partnerships, moving from dialogue to strategic partnerships, opening up a period of comprehensive development across all sectors. In Bali 2003, China is the first major country outside the region to sign Treaty of Amity and Cooperation with ASEAN with an aim to create important premise to ensure the security environment of the region. This will help promote the accession of major countries to this Treaty with ASEAN. Despite having an established strategic partnership with China, ASEAN countries are still concerning about Chinese threat to their existential security ("to be or not to be in the region"), but they regard China' s economic rise as giving opportunity to all ${ }^{56}$.
Could ASEAN Counterbalance to China in the Region?

\section{Evidences for the "Yes" Answer}

A number of measures have been taken by ASEAN to resolve disputes in the South China Sea or to build trust among the parties to curb potential conflicts and prevent further military clashes, mainly through means of negotiation. Those measures are carried out collectively by the ASEAN as a whole, but they are impossible to be taken individually by any single ASEAN member state. A number of documents regulating the national behavior in the South China Sea have been developed, such as the Treaty of Amity and Cooperation in Southeast Asia in 1976, the Treaty of Southeast Asia Nuclear Weapon Free Zone in 1995 and the Manila Declaration in 1992 (the first statement expressing the common position of ASEAN countries on the issues of South China Sea). The Declaration on the Conduct of parties in the South China Sea (November 4, 2002) is considered as a breakthrough in ASEAN-China relations on the South China Sea, and also shows ASEAN's significant role in settling disputes in the region. Prior to the DOC, ASEAN had the idea of developing a Code of Conduct for parties in the South China Sea (COC). ASEAN adopted diplomatic measures, namely through multilateral negotiations between nations in the region and with China to launch a Code of Conduct on the South China Sea. In this context, ASEAN is capable of addressing cross-border issues of the region that any single country cannot do. Disputes over sovereignty, territory, security, maritime safety, terrorism, arms control, human and drug trafficking, climate change, water security, epidemics, migration and displacement, financial imbalances and international trade are regional or even interregional problems. Due to the scale of these problems, most of them are at regional level, their settlement should be carried out collectively, through regional mechanisms ${ }^{57}$. In this sense, ASEAN is an appropriate counterpart for China in solving common regional security issues of both military and non-military nature.

In fact, China has been playing a leading role in the development of ASEAN-China relations, especially after 2003, when the two sides kicked off the process of realization of strategic partnership relations. This role has helped China to further improve its influence in ASEAN, particularly in the period 2003-2008. China's political and diplomatic presence is everywhere. At the regional level, the Chinese delegation to ASEAN was formed. At the national level, in addition to the Chinese embassy in the capital of ASEAN countries, 
Chinese consulates are present in most cities and major economic centers in ASEAN. Chinese leaders are welcomed in the capital of most ASEAN countries. China not only represent $s$ an emerging powerhouse, China has also made itself one of the great financial resources that many ASEAN countries have been waiting for. In the period 1997-2010, many ASEAN leaders have praised China and its generous financial support for their countries. Economically, since 2009, China has been ASEAN's largest trading partner and the second largest export market ${ }^{58}$. ASEAN and China have had many negotiations on the COC (Code of Conduct of parties in the South China Sea) since China took over Mischief Reef in the Spratlys in 1995. The two sides exchanged COC drafts in March 2000, but due to many disagreements, the two sides could not reach the COC, only the Declaration on the Conduct of parties in the South China Sea (DOC) was adopted in 2002. On 6 August 2012, the ASEAN and China's Foreign Ministers adopted a draft of COC framework in Manila. According to the ambassador to China in ASEAN, Beijing plans to conduct more maritime cooperation programs with ASEAN such as joint maritime exercises, organizing workshops on coastal ecosystem assessment and conservation strategy in South China Sea, training on remote sensing satellite in marine environment, and opening a conference on communication safety and navigation in the South China Sea ${ }^{41}$. It seems that despite its predominant role in Asia, China needs same size or similar size partners for development and cooperation in order to solve common security issues, to support and benefit from mutual existence.

At a press conference on the morning of August 31, 2018, representatives of the ASEAN-China Information Sharing Forum declared that ASEAN and China continued to strengthen cooperation in connecting information and developing digital economy, to improve the quality of cultural exchanges, economic, investment and trade cooperation. The Forum focused on building information platforms in five key areas: (1) infrastructure, (2) information sharing, (3) technology cooperation, (4) economic and trade services and (5) human exchange. Accordingly, this year's Forum will was held from 12 to 18 September, in Nanning, Guangxi province, at the same time as the ASEAN-China Fair (CAEXPO) and the ASEANChina Business and Investment Summit (CABIS), one of the most important activities in the framework of ASEAN-China cooperation. The main topic is building the digital economy, the Forum gathered more than 2,000 delegates who are government officials, representatives of ministries, sectors and localities; experts and scholars from universities and research institutes; business leaders from ASEAN countries and China. The Forum featured nine sessions on digital economy on 5D technology, network culture development, satellite application cooperation, e-commerce in order to exchange and make recommendations on future cooperation between ASEAN and China, to promote policy dialogue, connect infrastructure, trade, capital and people exchange ${ }^{59}$. As seen above, ASEAN is appropriate partner for China in all aspects, not only in solving multifaceted common security and economic issues but also multilateral exchange and cooperation for mutual development towards future shared vision in the context of digital economy and Industrial Revolution 4.0. Realistically speaking, China cannot benefit from relationship with ASEAN taking individually relationship with each of its member state.

\section{Evidences for the "No" Answer}

China and the US are increasingly engaged in ASEAN, involving ASEAN in their geopolitical forces. SinoUS competition puts ASEAN ahead of the big challenge of recognizing and dealing with external pressures $^{50}$. Tim Huxley, regional director of the International Institute for Strategic Studies (IISS) in Asia, at the World Economic Forum (WEF) ASEAN 2018 confirmed that the region's balance of power is being challenged, with ASEAN nations being in an increasingly vulnerable position. Countries in this region are divided on their support for the US and China. He said at a session on the new power balance at the WEF ASEAN 2018 that China's influence in the region is on the increase, with its economic strength and geopolitical implications. In the South China Sea, China built and militarized islands, procuring arms such as missiles, submarines and fighters. Huxley emphasized that China set out important strategic objectives in the South China Sea not only as a matter of territorial sovereignty, but for the purpose of gaining access to the maritime resources under South China Sea. Huxley said that ASEAN had multilateral and bilateral consultations on the South China Sea issues, but there seemed to be no overall solution, and he is quite concerned about this ${ }^{60}$.

Regarding the China's strength and ASEAN's passive role in counterbalancing this superpower, to prominent question from Xinhua News Agency's Bangkok correspondent: "In the context of China's continual growth and expansion, Xi Jin Ping's initiative, such as 
the OBOR (One Belt and One Road), it can be seen a clear imbalance of power over the South China Sea, while ASEAN seems to be relatively quiet and of no concern at all. In this circumstance who will take the lead in counterbalancing China?"61. Marty Natalegawa responded: "We need to avoid trying to counterbalance China, which can be considered a meaningless effort, not just for ASEAN, but even for the US. All political and social movements of ASEAN countries will be affected by China's unprecedented power. So the question is not how to counter it, but how to manage it and live with this strategic imbalance" ${ }^{62}$. Competition between the two superpowers pow er in the region is dividing ASEAN bloc and ASEAN nations within, and we have seen many methods of protection, for example the withdrawal of the Cambodian opposition. This is the moment of time when ASEAN needs to get the best of current overall situation in the region or otherwise things will get worse ${ }^{63}$.

\section{CONCLUSIONS AND DISCUSSION}

The article summarizes current literature on international relations and security issues, puts forward some economic and political context appraisals and analyzes the ongoing situation of ASEAN in the relation to China in multiple aspects. Hereafter, more details associated with theoretical and practical contributions of this article are presented as major achievements of authors:

\section{Conclusion and Theoretical contribution}

First and foremost, the article gives full understanding of complex essence (military and non-military nature) and multiple definitions of national security in context of the ongoing globalization process. National security could be defined by its specific goals, by using succession approach and be regarded as a process conditioned by global or national context, condition and situation.

Secondly, the article present a detailed overview of contemporary security issues, related concepts and notions (such as challenge, current threat and potential threat, real threat and sense of threat), their multidimensional (social, cultural, technological, economic, political, diplomatic and military character), multi-perspective (internal, external), multifaceted (conventional and unconventional) and multi-level (global, regional supranational, national, social groups, families and individuals) character. All of that are based on a sound and solid literature review of relevant, multiple sources of world-class security related scientific journals.
Thirdly, when it comes to the research methodology on security issues, the article proposes to borrow from disciplines of social sciences. However, security science should preserve both its originality (to have own distinctive specifics and to be separated from other scientific disciplines) and multidisciplinary character (to be at the crossroad of well-rounded traditional political science, sociology, psychology, etc.).

Fourthly, in terms of framework of research on security issues, at the global and regional level of security analysis the article propose classification into conventional and unconventional issues, at the national level - external and internal issues accordingly. The article provides justification for those classifications and highlights the critical importance of unconventional issues at the global level and, respectively, internal issues at national level.

Finally, as globalization shapes processes that take place in all spheres of human activity, including economy and security, those are areas of basic importance for human functioning in the contemporary world, mutually penetrating and dependent on each other. The article attaches important role of national government in retaining global benefits and security for its citizens and enterprises, at the same time limiting all possible negative consequences. As a result, for the need of conducting comparative study between ASEAN and China, a comprehensive research scheme was adopted that embraces those two parallel aspects of security issues: macroeconomic security and existential security. The first one is associated with general economic power, trade and investment position and advantage while the second is related with geopolitical identity (to be or not to be), geo-strategic position and general geo-military capability of each researched object: ASEAN or China.

\section{Discussion and recommendation}

The article addresses a very interesting topic of security science and security issues (strategic counterbalance) of the well-known research objects (ASEAN and China), and is based on strong relevant empirical materials to support arguments of many hypotheses formulated and statements declared. As a basis for further detailed analysis, at the beginning, the article gives an overview over ASEAN-China relationship and a full insight into the development history of each of them. In the most important section of the article, the comparative study between ASEAN and China based on the proposed comprehensive research scheme, many arguments are put forward to justify 
that China's dominant position in the overall relationship with ASEAN bloc, both in terms of macroeconomic security issues and political existential security issues. China is both an economic and military powerhouse in the region. Looking at the trade and investment relationship over past years, most of ASEAN countries suffered from chronic trade and investment deficit with China. ASEAN countries invest directly more in China than China invest in ASEAN. It is totally unacceptable and must change soon, given the trend of colossal outflows of Chinese FDI around the world, especially in Africa. The real problem of ASEAN is not how strong and how big it is but is that ASEAN countries are not internally united to exert common stance toward China in many aspects of their strategic economic and security relationship. This is similar to the European Union (EU) in counterbalancing the US economic hegemony. The problem is not the size and scale of EU economy. As an open bloc, it could be enlarged by admitting new members from Eastern Europe and Balkan region to become the largest economy in the world. The problem is how EU can be internally united to elaborate common stance toward the US and the world in many strategic issues and to avoid the next exit of current member states and the uncomfortable situation of the union of two speeds. For both the EU and ASEAN, it is better to be smaller but internally united and strongly committed rather than to be a big but loose confederation of a large number of member states. ASEAN should show more solidarity and be strongly integrated within to avoid being treated as buffer zone or an area of geo-political domination and strategic game between China and US. This is the only possible way for ASEAN to counterbalance China or any other economic and political forces in the region or outside.

\section{COMPETING INTEREST}

The authors declare that they have no conflicts of interest.

\section{AUTHOR'S CONTRIBUTION}

Nguyen Hoang Tien has done the research work of the article; Ha Van Dung has revised the article according to the Editor's requirements.

\section{ABBREVIATIONS}

ACFTA: ASEAN-China Free Trade Area ARF: ASEAN Regional Forum ADMM: ASEAN Defense Ministers Meeting AEC: ASEAN Economic Community FDI: Foreign Direct Investment
WTO: World Trade Organization

FTA: Free Trade Area

OBOR: "One Belt One Road"

GDP: Gross Domestic Product

COC: Code of Conduct

CAFTA: China-ASEAN Free Trade Area

ODA: Official Development Assistance

APSC: ASEAN Political Security Community

DOC: Declaration on the Conduct

CAEXPO: China- ASEAN Expo

CABIS: China-ASEAN Business and Investment Summit

WEF: World Economic Forum

\section{REFERENCES}

1. China. China-ASEAN relationship in recent years; 2018. (date of access: 30.10.2018). Available from: https://www.biendong.net/goc-nhin-moi/7045-quan-hetrung-quoc-asean-thoi-gian-gan-day.html.

2. China. China to seduce ASEAN countries; 2018 . (date of access: 30.10.2018). Available from: http://docbao.vn/the-gioi/trungquoc-tung-don-quyen-ru-cac-nuoc-asean-tintuc366241.

3. Yue CS. ASEAN-China Economic Competition and Free Trade Area. Asian Economic Papers. 2005;4(1):109-147. Available from: 10.1162/asep.2005.4.1.109.

4. Wikipedia; 2018. (accessed October 20, 2018). Available from: https://en.wikipedia.org/wiki/Security.

5. Gould J, Kolb WL. A dictionary of the Social Science. London; 1964.

6. Rotfeld AD. European safety system. Warsaw: PISM publisher; 1990.

7. Jemiolo T, Dawidczyk A. Introduction to safety research methodology. AON, Warsaw; 2008.

8. Grosset R, Anszczak M. Science in security. Enterprise of the Future. 2015;1(22):84-93.

9. Jokubauskas V. Threats and challenges to the security and stability of the state of Lithuania: historical perspective. Journal of Security and Sustainability Issues. 2017;6(4):673-690. Available from: http://doi.org/10.9770/jssi.2017.6.4.

10. Korycki S. Legal principles of implementation of national security management system in Poland. Enterprise of the Future. 2017;3(32):96-111.

11. Pluta K. Evolution of Polands strategic goals in XXI century - comparative analysis of national security strategies. Enterprise of the Future. 2017;1(30):9-20.

12. Maciejczyk R. Information in the internal security system. Enterprise of the Future. 2017;1(30):41-53.

13. Avdeev V, Avdeeva O, Rozenko S, Znamerovskiy E, Kiselyov E. Crime of the terrorist character and extremist orientation in the Russian Federation: State and measures of counteraction. Journal of Security and Sustainability Issues. 2017;7(2):359368. Available from: http://doi.org/10.9770/\%20jssi.2018.7.2.

14. Stanczyk J. Modern understanding of security. In: Institute of Political Science, Polish Academy of science. Warsaw; 1996.

15. Multan W. International security in nuclear era. PISM, Warsaw; 1991.

16. Klimkiewicz S. International issues. Warsaw; 1980.

17. Jemiolo T. The impact of migration on the Polish security. Enterprise of the Future. 2016;4(29):100-111.

18. Kukulka J. Security and European cooperation: mutual independence and conflict of interest. International Issues. 1982;31.

19. Dukaczewski M. NATO - a chance for continuation of open doors policy. Enterprise of the Future. 2015;3(24):40-47.

20. Krysinski S. NATO as the guarantor of Polands security. Enterprise of the Future. 2016;2(27):16-24. 
21. Makštutis A, Balkytė A, Tumalavičius V. Security, sustainability and competitiveness: benchmarking attempts. Journal of Security and Sustainability Issues. 2012;2(1):5-12. Available from: www.lka.lt/index.php/lt/217049/.

22. Brown LR, Flavin C, French HF. Report on state of the world at the threshold of new millennium. Warsaw: KiW; 2000.

23. Baylis J, Smith S. Globalization of worlds politics. Introduction to international relations. Cracow: Jagiellonian University; 2008.

24. Guliyeva A, Britchenko I, Rzayeva U. Global security and economic asymmetry: a comparison of developed and developing countries. Journal of Security and Sustainability Issues. 2018;7(4):707-718. Available from: http://doi.org/10.9770/jssi. 2018.7.4.

25. Telep J, Telep D. Globalization in economy and security. Enterprise of the Future. 2017;3(32):49-62.

26. Mical M. Globalization process in contemporary world. Zeszyty Naukowe Zakadu Europeistyki Wyszej Szkoy Informatyki i Zarzdzania w Rzeszowie. 2008;3(8).

27. Czaja J. Cultural security of Poland. Warsaw; 2004.

28. Kaczmarek B. Social and economic consequences of globalization. Annales Ethics in the economic life, Łódź. 2014;17(1).

29. Ruža A, Ruža I, Raščevskis V, Vorobjovs A, Murasovs V. Safety and security in the EU: Perception of the Latvian residents. Journal of Security and Sustainability Issues. 2016;5(3):365376. Available from: http://doi.org/10.9770/jssi.2016.5.3.

30. Štiglic D. Towards security through economic policy: a Baldwin approach. Journal of Security and Sustainability Issues. 2017;7(1):67-78. Available from: http://doi.org/10.9770/jssi. 2017.7.1(1).

31. Lankauskienè T, Tvaronavičienè M. Security and sustainable development: approaches and dimensions in the globalization context. Journal of Security and Sustainability Issues. 2012;1(4):287-298. Available from: www.lka.lt/index.php/lt/ 217049/.

32. Kabát L, Filip S, Filipová L. Safety measurement peculiarity in selected countries. Journal of Security and Sustainability Issues. 2017;6(3):343-356. Available from: http://doi.org/10. 9770/jssi.2017.6.3.

33. Štitilis D, Pakutinskas P, Kinis U, Malinauskaitè I. Concept and principles of cyber security strategies. Journal of Security and Sustainability Issues. 2016;6(2):197-210. Available from: http: //doi.org/10.\%209770/jssi.2016.6.2.

34. Kuc BR. Methodological assumptions of the science of safety. Enterprise of the Future. 2015;2(23):9-20.

35. Buzan B, Waever O, Wilde JD. Security as a New Framework for Analysis. London; 1998.

36. Ploch AJ. Globalization consequences for social and economic security. Enterprise of the Future. 2017;3(32):63-75.

37. Telep J, Telep D. Transformation of terrorism: source of increased security risk. Enterprise of the Future. 2017;1(30):920.

38. Philippines. Philippines and the worry with banana war with China; 2018. (date of access: 10.11.2018). Available from: http: //vics.vn/TinTuc/TinKinhTe/178294/philip\%20pines-khondon-vi-quotchien-tranh-chuoiquot-voi-trung-quoc.aspx.

39. Laos. Lao-China railway construction: 5 years, 6 billion USD, Bao moi (New Newspaper); 2018. (date of access: 10.11.2018). Available from: https://baomoi.com/xay-tuyenduong-sat-lao-trung-quoc-5-nam-6-ty-usd/c/21179140.epi.

40. Burma. Hundreds of Burmese protesting against China's pollution, Labor (Lao dong); 2018. (date of access: 10.11.2018). Available from: https://laodong.vn/the-gioi/hang-tram-nguoi- myanmar-bieu-tinh-phan-doi-trung-quoc-gay-o-nhiem548956.bld.

41. ASEAN. ASEAN and China agree on the Code of Conduct in the South China Sea; 2018. (date of access: 10.11.2018) Available from: https://www.rfa.org/vietnamese/news/ internationalnews/asean-and-china-agreed-on-the- uniquedocument-of-coc-07312018082800.html.

42. Trang M. China - ASEAN trade turnover at record high, Bnews; 2018. (date of access: 10.11.2018).

43. Tuyen $\mathrm{N}$. Vietnam lost more than $\$ 150$ billion when doing business with China, Dan Tri Newspaper; 2018 (date of access: 10.11.2018). Available from: https: //dantri.com.vn/kinh-doanh/viet-nam-tham-hut-hon-150ty-usd-khi-lam-an-voi-trung-quoc-20180523073003674.htm.

44. China. China's capital in Southeast Asia is rising sharply 2018. (date of access: 10.11.2018). Available from: http://vneconomy.vn/the-gioi/von-trung-quoc-vao-dongnam-a-dang-tang-manh-20170531120444969.htm.

45. Hong Q. ASEAN is China's third largest trading partner Voice of Vietnam; 2018. (date of access: 10.11.2018) Available from: https://vov.vn/kinh-te/thi-truong/asean-ladoi-tac-thuong-mai-lon-thu-3-cua-trung-quoc-825263.vov.

46. Kim D. China's economic downturn affects Southeast Asia more than Brexit, BNEWS; 2018. (date of access: 10.11.2018). Available from: https://bnews.vn/kinh-te-trung-quo-c-giamtoc-tac-dong-den-dong-nam-a-nhieu-hon-brexit/18719. html.

47. UN; 2018. (date of access: 10.11.2018). Available from: https: //comtrade.un.org/.

48. China; 2018. (date of access: 10.11.2018). Available from: http: //english.customs.gov.cn/.

49. Mahbubani K. ASEAN at 50, Project Syndicate; 2017.

50. Le VC. ASEAN - mission of small countries to lead bigger countries, Báo Mới (New Newspaper); 2017.

51. Trung $H$. US-China relationship in the fight for influence in Southeast Asia. The Diplomat. 2018;.

52. ASEAN. An introduction to ASEAN; 2018. ASEAN department in Vietnam's Ministry of Foreign Affairs and Vietnam Secretary Committee in ASEAN.

53. Kieu T. How are generations of Chinese leaders determining their political thought?, Báo Thời Đại (Time Newspaper); 2017.

54. Chang GG. The Coming Collapse of China. The National Interest. 2018;

55. Nguyen HS, Dang TC. A discussion on China's maritime power strategy after the XVIIIth congress. Journal of International Studies. 12/2014;4(99).

56. Luu VH. About China-ASEAN relations from the post-Cold War period. Journal of Political Theory. 2015;8.

57. H TT. ASEAN's role in Asia-Pacific power structure in the 21st century. Journal of Communist. 2018;

58. Tran $\mathrm{XH}$. The implications of the ASEAN-China relationship for both sides. Duy Tan University; 2017.

59. Huu H. ASEAN and China are strengthening cooperation in the digital information and economy, Nhân Dân (The People); 2018.

60. Huxley T. The role of ASEAN in power structure in Asia Pacific in XX century. Journal of Communist. 2018;

61. ASEAN. ASEAN - division but still of hope, Xinhua News Agency in Bangkok, BBC News; 2018.

62. Natalegawa M. ASEAN - division but still of hope, BBC News; 2018.

63. Pongsudhirak T. ASEAN - division but still of hope, BBC News; 2018. 


\title{
ASEAN có thể là đối trọng kinh tế và chính trị trong khu vực đối với sự trỗi dậy của Trung Quốc?
}

\author{
Nguyễn Hoàng Tiến ${ }^{1,}{ }^{*}$, Hà Văn Dũng ${ }^{2}$
}

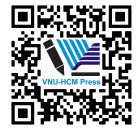

Use your smartphone to scan this QR code and download this article

\section{TÓM TẮT}

An ninh quốc gia là một trong những yếu tố quan trọng nhất đối với xã hội, nền kinh tế và hệ thống chính trị của mỗi quốc gia. Đặc biệt, nó vô cùng quan trọng đối với sự ổn định, bền vững và thịnh vượng của mỗi quốc gia. Ngoài ra, đây cũng là ưu tiên hàng đầu đối với tất cả các nước ASEAN phải đối phó với Trung Quốc đang trỗi dậy liên tục trong tất cả các khía cạnh phát triển của khu vực châu Á - Thái Bình Dương. Bài báo này sử dụng phân tích nghiên cứu tính uống kết hợp với phân tích thực nghiệm so sánh để điều tra và tìm ra câu trả lời cho câu hỏi được nêu trong tiêu đề. Bài báo tiếp cận và coi an ninh và khoa học quân sự là lĩnh vực liên ngành của nghiên cứu đương đại. Đồng thời các lĩnh vực này được coi là một trong nhũng nhánh nghiên cứu của khoa học xã hội. Vào đầu thế kỷ 21, mối quan hệ kinh tế cũng như quan hệ địa chính trị giữa Trung Quốc và ASEAN đã có nhiều tiến bộ và thay đởi tích cực theo hướng đi đúng đắn, phù hợp với các nguyên tắc chung về phát triển hòa bình và bảo đảm an ninh trong khu vực. Tuy nhiên, mối quan hệ hiện tại này vẫn còn nhiều khó khăn và trở ngại mà hai bên cần giải quyết và khắc phục để hưởng lợi từ những tiềm năng hiện có của nhau. Mục tiêu đầu tiên của bài viết này là tập trung vào mối quan hệ phức tạp chung giữa ASEAN và Trung Quốc có thể gây ra mối đe dọa và nguy hiểm thực sự cho các an ninh quốc gia các nước ASEAN do thiếu khả năng đối trọng với Trung Quốc đang trỗi dậy ở khu vực Châu Á Thái Bình Dương. Mục tiêu thứ hai của bài viết là đề xuất một số khuyến nghị hữu ích và giải pháp khả thi để bảo vệ sự an toàn của người dân, an ninh xã hội và nền kinh tế cùng với sự tồn tại chính trị của khối ASEAN.

Từ khoá: ASEAN, Trung Quốc, phát triển kinh tế, vấn đề quân sự, Biển Đông

\footnotetext{
${ }^{1}$ Trường Đại học Quốc tế Sài Gòn

${ }^{2}$ Trường Đại học Ngân hàng

Liên hệ
}

Nguyễn Hoàng Tiến, Trường Đại học Quốc tế Sài Gòn

Email: nguyenhoangtien@siu.edu.vn

Lịch sử

- Ngày nhận: 3/1/2019

- Ngày chấp nhận: 28/4/2019

- Ngày đăng: 30/9/2019

DOI : 10.32508/stdjelm.v3i3.565

\section{Check for updates}

\section{Bản quyền}

๑ ĐHQG Tp.HCM. Đây là bài báo công bố mở được phát hành theo các điều khoản của the Creative Commons Attribution 4.0 International license.

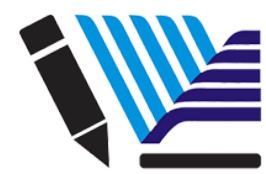

VNU-HCM Press
Trích dẫn bài báo này: Hoàng Tiến $\mathrm{N}$, Văn Dũng $\mathrm{H}$. ASEAN có thể là đối trọng kinh tế và chính trị trong khu vực đối với sự trỗi dậy của Trung Quốc?. Sci. Tech. Dev. J. - Eco. Law Manag.; 3(3):247-261. 